\title{
A imagem informe: reflexões sobre a alteridade dos corpos sem rosto
}

\author{
João Victor de Sousa Cavalcantel \\ https://orcid.org/0000-0001-6389-7861 \\ I - UFPE \\ Recife (PE), Brasil
}

Resumo: O objetivo deste ensaio é levantar questionamentos sobre as possibilidades de alteridade dos corpos sem rosto, tendo como preocupação central a pergunta: quanto podemos decompor a figura humana para que esta permaneça humana? Partindo de um conjunto de imagens que trazem a desfigura como elemento pictórico central, o texto discute as possibilidades de construção e acesso ao outro na imagem. Tomamos como ancoragem conceitual e metodológica o pensamento de Georges Bataille, notadamente o conceito de informe, que nos sugere pensar a alteridade a partir de uma semelhança transgressiva, baseada na diferença e na decomposição das formas. O texto busca investigar que alteridade é possível diante dos corpos sem rosto e como isso reverbera nas proposições da cultura visual contemporânea.

Palavras-Chave: rosto; Georges Bataille; alteridade; informe; cultura visual.

Abstract: The formless image: reflections on the otherness of faceless bodies - The aim of this essay is to raise questions about the possibilities of alterity of the faceless bodies, taking as central concern the question: how much can we decompose the human figure so that it remains human? Starting from a set of images that bring the disfigure as a central pictorial element, the text discusses the possibilities of construction and access to the other in the image. We take as conceptual and methodological anchoring the thought of Georges Bataille, notably the concept of formless, which suggests us to think of otherness from a transgressive similarity, based on the difference and the decomposition of forms. The text seeks to investigate what alterity is possible before faceless bodies, and how this reverberates in the propositions of contemporary visual culture.

Key words: face; Georges Bataille; otherness; formless; visual culture.

\section{Introdução}

Os quinze números da Documents, periódico editado por Georges Bataille nos anos 1929 e 1930, trazem uma coleção de imagens e textos que circulavam entre a etnologia 
e a arte, com uma proposta que buscava na noção de primitivo a medula antropológica do pensamento modernista francês do entre guerras. A obra de Bataille apresenta um percurso no qual a filosofia ${ }^{1}$ faz ecoar questões ligadas à estética, à antropologia, à teoria das religiões, como observado tanto na obra ensaística quanto na ficcional, em romances em que o erotismo ocupa um lugar explícito, evidenciando o apreço que Bataille manteve pelo pensamento do Marquês de Sade. É notória, também, a influência de Nietzsche: o projeto de uma filosofia a golpes de martelo vai ao encontro, na Documents, da demanda de discutir o crepúsculo da figura humana e de pensar o conceito e a forma do antropos como documentos do tempo.

Na revista, a tradicional noção de humano (a saber, patriarcal, humanista e antropocêntrica) é golpeada no conjunto de textos montados junto a fotografias, ilustrações, recortes de jornal etc. Bataille (apud MORAES, 2002) leva adiante o projeto surrealista de desfiguração da imagem humana, mas de forma mais radical, trazendo um apelo agônico e sádico à dilaceração da carne. Pensar o corpo e o sujeito como seres fragmentados surge para as vanguardas do início do século XX como um projeto em andamento: o imaginário que remonta à decapitação, à guilhotina, à mesa de dissecação e às tecnologias de imagem, como o estereoscópio e a câmara escura, que convocam e abstraem simultaneamente o corpo e a visão do observador (CRARY, 2012), monta uma iconografia em que o desprendimento entre corpo, olhar e imagem aparece como um sintoma da cultura visual na modernidade europeia.

O que Bataille propõe é conferir um caráter ontológico e epistemológico a esse antropomorfismo dilacerado, que deforma a figura humana ${ }^{2}$ de modo violento. A experiência humana em Documents, que reverbera ao longo da obra batailleana, traz a materialidade da figura como tensionamento central das noções de humano e de alteridade, a partir de uma crítica à noção de forma, cujo contraponto o autor vai encontrar no conceito de informe. Tendo como norte a montagem de figuras humanas que Bataille expõe na Documents, este artigo propõe pensar a figura humana possível aos corpos sem rosto. A partir de imagens que trazem o rosto desfigurado ou o rosto ausente como foco da representação, interessa-me discutir a fabricação de monstruosidades na imagem e o modo como estas tensionam as possibilidades de reconhecer-se no outro. Questiono-me: quanto podemos decompor a figura humana para que esta permaneça ainda humana? Qual alteridade é possível aos monstros sem rosto?

1 No final dos anos 1920 e começo da década de 1930, Bataille não tinha uma formação técnica em filosofia, tendo formação na École des Chartes como bibliotecário e arquivista. A filosofia entra na obra do jovem Bataille pelas leituras de Nietzsche e pelos cursos sobre Hegel, ministrados por Alexandre Kojève.

2 Neste trabalho, figura é entendida a partir do escopo conceitual da revista Documents, notadamente nos ensaios A Linguagem das Flores e Figura Humana, ambos assinados por Georges Bataille. Figura, para o autor, é entendida a partir de um pensamento materialista encontrado em Bataille, que busca pensar o valor de gasto das coisas. Nesse sentido, figura aproxima-se da ideia de aspecto material, ou aspecto sensível, "presença real" dos objetos, a despeito de sua existência interpretativa ou simbólica. Para o autor, é no aspecto material/sensível, e não na palavra que se encontra "o valor decisivo das coisas" (BATAILLE, 2018, p.75). Dessa forma, o conceito batailleano de figura aproxima-se mais de uma revisão estética do materialismo marxista, da materialidade visual das formas, do que da discussão sobre o figural e o figurativo encontrada, por exemplo, nas analises de Deleuze sobre Francis Bacon, cuja elaboração distancia-se do que pretende este artigo. 
O antropomorfismo dilacerado dos corpos sem rosto sugere um apagamento do sujeito como portador de uma identidade e o conduz a zonas de indeterminação sígnica em que as noções culturais e históricas de mesmo e de outro já não sustentam a diferença. As discussões deste texto partem do pressuposto de que é na própria ambiência da imagem que pode surgir uma alteridade possível, diante da perspectiva de que, eximindo-se de suas propriedades pictóricas e informativas, a imagem reclama para si uma existência ontológica própria, uma vida sensível que supõe uma outridade específica, e não aquela baseada na mimese. O texto parte de uma montagem de imagens que dialogam por trazerem a figura humana informe como reclame pictórico. O intuito é menos analisar semioticamente as imagens que partir delas como figuras inquietantes do saber visual contemporâneo. Uso semelhante é formulado na Documents, em que conceitos e imagens não se explicam mutuamente e são dispostos sem a hierarquia analítica entre teoria e objeto. Junto ao conceito de informe, tomo as imagens, não como um corpus tradicional, mas como ancoragem para formular as questões centrais a este artigo.

Metodologicamente, o artigo organiza-se ao redor do conceito de informe de dois modos: como um operador conceitual, o informe pode ser pensado como uma categoria desclassificadora que aproxima imagens e conceitos distintos entre si a partir de uma ideia de semelhança transgressiva, que remete ao dinamismo das imagens no pensamento simbólico, em que a materialidade dos signos ocupa a centralidade das operações de sentido; em segundo lugar, o conceito nos orienta como um modo de organização das imagens, entendido como uma montagem figurativa (DIDI-HUBERMAN, 2015), como realizado na própria Documents, na qual a relação entre imagens e textos díspares buscava criar um pensamento dialético, que propõe pensá-las como um conjunto, e não em seus significados individuais.

\section{O informe e a desfiguração da carne}

O romance O Rosto de um Outro, do escritor japonês Kobo Abe (2015), traz a narrativa de um cientista que, após um acidente com ar líquido, perde o rosto. Homem da ciência, o protagonista do livro, cujo nome não é revelado, empreende um movimento de racionalizar a perda, como se perder o rosto fosse o mesmo que perder um braço, este facilmente substituível por uma réplica maquínica. Na contramão desse movimento, o personagem vê-se diante de um abismo de comunicabilidade, a começar pela relação com os colegas de trabalho, culminando no convívio com a esposa, que passa a baixar o olhar diante das feições vazias do que fora o rosto do marido, agora coberto por bandagens, ou por um ninho de sanguessugas que promoviam a circulação sanguínea da ferida.

O entrave da relação conjugal, e os dilemas secundários sobre caminhar nas ruas com bandagens envolvendo a cabeça, reverberam na narrativa em primeira pessoa, escrita como uma carta de despedida à esposa, que discute a instituição rosto. O narrador passa 
a discorrer sobre os significados do rosto a partir de sua inexistência e de sua busca por confeccionar uma máscara adequada para substituir as feições perdidas. À pesquisa sobre máscaras sucede uma investigação sobre anatomia do rosto e noções fisiológicas sobre identidade e temperamento. Por exemplo, um rosto com área central deprimida, esquelético, com bochechas acentuadas e carnudas seria, na avaliação do personagem, mais introvertido e conciliador, enquanto um rosto adiposo e de área central protuberante tenderia a ser hostil e confrontador, fisionomia escolhida por ele.

Munido dessas informações, o cientista confecciona uma máscara de encaixe perfeito, mas opta por uma anatomia cuja personalidade diverge da sua. Em uma passagem, ele afirma: "se até monstros são seres criados, seres humanos também podem sê-lo" (ABE, 2015, p. 87). A partir desse ponto, o leitor observa a construção de duas personas distintas mediadas pela máscara, esta utilizada para o convívio em sociedade de uma identidade forjada e hábil no trato social, enquanto o real rosto, o rosto inexistente, passa a habitar a penumbra. Cabe ao duplo sem rosto a tarefa de narrar a própria condição monstruosa de uma existência sem aparência e sem correspondente formal em um mundo de imagens. O rosto que narra sua experiência o faz diante da incomunicabilidade que impera em todo o livro de Abe: sem rosto, o personagem vivencia uma experiência sensível própria, contudo é inexistente como indivíduo social.

Tomo o romance de Abe (2015), publicado no Japão, em 1964, ainda sob forte influência dos ataques à Hiroshima e Nagasaki, como uma porta de entrada para pensar a alteridade possível aos entes sem rosto. Discuto esses espaços epistêmicos monstruosos, nos quais o debate sobre identidade colide com a impossibilidade de ver-se refletido no outro, que perturbam as "superfícies ordenadas e todos os planos que tornam sensata para nós a profusão dos seres, fazendo vacilar e inquietando, por muito tempo, nossa prática milenar do Mesmo e do Outro" (FOUCAULT, 2000, p. VIII). Esses hiatos na percepção do outro e do comum são levados a um limite conflituoso quando nos voltamos para os corpos sem rosto. No nível narrativo, ao personagem sem rosto cabe apenas relatar sua vivência. Quando essas questões tocam a imagem, quando o rosto desfigurado e inexistente alcança o repertório do imaginário, outras potências de alteridade são dispostas.

É o que encontramos nas figuras que me proponho a discutir neste ensaio: a primeira imagem traz uma mulher filmada pelo documentário A Casa é Escura (Khaneh siah ast, 1963), da cineasta iraniana Forough Farrokhzad, que mostra o cotidiano de uma colônia de leprosos, focando a questão humanista e o cuidado de si, e que traz as relações de comunicação intimamente atreladas à visualidade, em que um sentimento de comunidade se constrói mediante a decomposição do corpo pela doença. A imagem mostra o momento em que uma mulher jovem, com o rosto bastante comprometido, maquia-se diante de um espelho e averigua o resultado. $O$ gesto de cuidado e de embelezamento chega ao espectador como um hiato de empatia diante de uma imagem intolerável.

Em seguida, há a fotografia do artista iraniano Ebrahim Noroozi. A foto é parte de um ensaio chamado Victims of Forced Love (2012), que traz retratos de vítimas de ataques com 
ácido, motivados por crimes de ódio. A série traz personagens isolados, cuja deformidade os impede de convívio social. Na sequência, uma fotografia do ensaio Disco Night Sept. 11, do documentarista Peter van Agtmael, que exibe uma crônica visual sobre as guerras no Iraque e Afeganistão entre 2006 e 2013. Na imagem, um retrato de Bobby Henline, soldado americano e único sobrevivente de um atentado de uma explosão que o deixou com quase metade do corpo queimado.
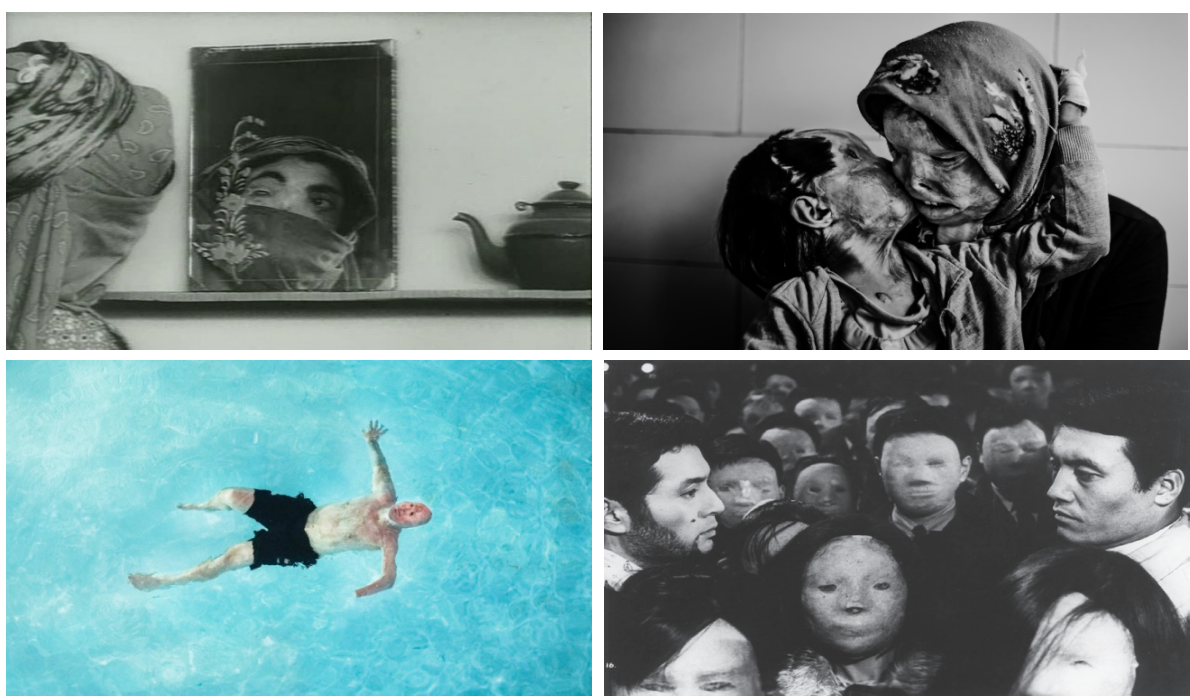

Fig. 1.

Os personagens documentados emparelham-se com o monstro de Kobo Abe, cuja adaptação para o cinema, de 1966, nos dá o quarto não-rosto da galeria de desfiguras. O enredo é semelhante ao do livro, com a particularidade de trazer o rosto apagado em primeiro plano, diante do espectador. As imagens elencadas se justificam pela repetição de um sentimento de incomunicabilidade que perpassa os personagens mostrados, que o compartilham com o protagonista de $O$ Rosto de um Outro, quando ele afirma que "o rosto de um monstro convida à solidão, e essa solidão produz o espírito do monstro" $(\mathrm{ABE}, 2015$, p. 77). As imagens trazem uma diferença radical que nega o sentimento de conforto presente na identidade, entendida como reconhecimento mimético, povoando uma ambiência mais próxima do agônico e do dilaceramento.

Estamos, portanto, no domínio do informe batailleano. O conceito faz parte de um projeto de Dicionário Crítico, levado a cabo nas edições da revista Documents. A montagem iconográfica da revista misturava imagens de arte tradicional, fotografias etnográficas, registros da natureza, imagens abjetas, grotescas, acompanhadas de textos que ofereciam outra experiência da relação palavra-imagem. Os textos e as figuras não se complementavam informativamente, mas promoviam uma fragmentação confusa da ideia de real e da ideia de forma. 
Essa montagem promovia o chamado baixo materialismo batailleano, como um modo de ruptura com o pensamento surrealista, o qual buscava na exploração do inconsciente a matéria de um possível pensamento humano. Para Bataille, era o excesso de real que traria esse caminho, daí sua busca pelo visceral, pelo erotismo, pela maldade, temas que vão permear toda a sua obra, filosófica e ficcional, como o caso d'A História do Olho, na qual o olho é rebaixado (daí a ideia de baixo materialismo) ao ânus como órgão principal da visão. Na carreira de Bataille, esse experimento filosófico tem inicio com a Documents que, segundo Georges Didi-Huberman (2015, p. 20), trazia "toda uma constelação de imagens que não passavam de desastres, isto é, de imagens reviradas, rompidas, imagens revirantes, nessa mesma qualidade".

O projeto da Documents correspondia a uma proposição de pensamento que tinha a imagem como orientação, como documento vivo, não como ilustração aos textos verbais ou como enigmas explicados por estes, mas dentro de um regime de pensatividade próprio, de presença, tomando a imagem como epistemologia para pensar a figura humana, esta "não mais como uma justa medida harmônica entre dois infinitos, mas um organismo destinado à desfiguração, à acefalia, ao suplício, à animalidade" (DIDI-HUBERMAN, 2015, p. 20).
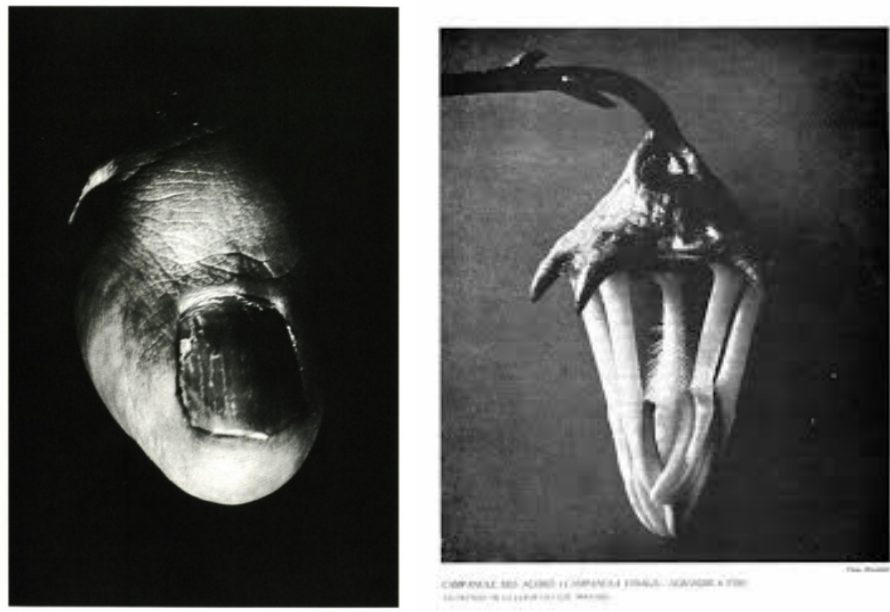

Fig. 2. Fotografias publicadas em Documents.

O conceito de informe atua como uma bula, uma recomendação sobre o que deveria ser um real dicionário, como uma crítica ao pensamento enciclopedista em que palavra e figura se explicam. O conceito expõe uma estrutura que sugere o desmonte de si mesmo, como um operador conceitual que obriga ao movimento e que afeta diretamente a ideia de forma, provocando sua capacidade inerente de deformar-se. Reproduzo o verbete:

Um dicionário começaria a partir do momento em que ele não desse mais o sentido das palavras, mas sim suas obrigações. Assim, informe não é somente 
um adjetivo com certo sentido, mas um termo que serve para desorganizar, exigindo, geralmente, que cada coisa tenha sua própria forma. Isto que ele nomeia não aponta um caminho fixo e pode ser facilmente despedaçado, da mesma forma que uma aranha ou um verme também o podem. De fato, para o contentamento dos acadêmicos, seria necessário que o universo tomasse forma. Toda a filosofia não tem outro objetivo: trata-se de dar uma roupagem ao que já existe, dar uma aparência matemática. Por outro lado, afirmar que o universo não se assemelha a nada e que ele não é nada além de informe retoma a ideia de que o universo é como uma aranha ou um escarro (BATAILLE, 2018, p. 147).

A heurística proposta por Bataille depreende uma crítica a uma metafísica substancialista, notadamente uma crítica à Hegel e à noção de uma marcha do espírito que preenche as formas sociais instituídas, como uma procura contínua de adequação entre a forma material e o espírito, que no léxico de Hegel confunde-se com a própria noção de cultura. O que Bataille parece sugerir, na contramão do pensamento estético hegeliano, é que cada coisa tenha sua própria forma, a forma de si mesma, e não seu próprio espírito, ou sentido, ou qualquer noção transcendental que pudesse prescindir da materialidade para ser entendida. Além disso, essa forma que cada coisa deveria ter é passível de ser facilmente despedaçada, transformada em formas outras. O informe convoca o materialismo e o fetichismo, conceitos correntes na crítica marxista, por outra via: o fetichismo, para Bataille, não é a alienação em relação à produção da mercadoria, mas sim a verdade da relação sujeito-objeto. Em um ensaio o autor diz: "desafio qualquer amador de pintura a amar uma tela quanto um fetichista ama um sapato" (BATAILLE, 2018, p. 250).

O materialismo e o fetichismo em Bataille são revigorados pela noção de informe como categoria desclassificadora. Há na configuração de imagens propostas pela Documents um apelo ao baixo, ao vil, ao despedaçado, a imagens que não são além do que são e que reclamam para si uma forma física (não metafísica). Há um imperativo do valor de uso, que demanda ao espectador colocar-se no mesmo nível do objeto. O documento é, portanto, um objeto desprovido de valor de troca ou de valor de culto. Não está alienado do corpo do sujeito, mas se relaciona com ele como um sapato nas mãos de um fetichista.

Se Bataille afirma que o universo não se parece com nada, que é informe, passível de ser comparado às figuras do baixo materialismo, como uma barata ou um escarro, ele afirma também que o humano não pode mais ser parâmetro do saber, sequer parâmetro da imagem, uma vez que a figura humana também não pode parecer-se com nada, talvez com um escarro ou uma aranha, mas não mais como o vitruviano de Leonardo. O pensador francês faz um movimento contrário às epistemologias ocidentais que trazem a semelhança como um parâmetro de compreensão do mundo (FOUCAULT, 2000). A distância temporal entre as edições da Documents e os escritos de Walter Benjamin é curta, mas não é possível afirmar com certeza se Benjamin conhecia o léxico de Bataille quando escreveu As Doutrinas das Semelhanças, em 1933. 
Benjamin afirma a semelhança como um dom do qual dispõe o homem, uma capacidade mimética que dá molde às transformações culturais. Em Benjamin (1984, p. 133), a semelhança é também vista como um desejo, "um fraco resíduo da violenta compulsão, a que estava sujeito o homem, de tornar-se semelhante e de agir segundo a lei da semelhança". O projeto do informe se coloca como um movimento contrário, que tensiona o deslocamento em direção ao semelhante. A figura humana não é vista aqui como um espelhamento do cosmos, ou vice-versa, nada tão elevado ou transcendente. A imagem do homem é aparentada a um escarro, algo baixo, facilmente desfeito e que não se parece com nada além de si mesmo. O informe desclassifica.

O antropocentrismo é substituído pelo antropomorfismo, mas não de qualquer modo: não se trata da transformação da forma humana numa coisa outra, ou da descentralização da experiência humana. A experiência da semelhança provocada pelo informe é aproximada do ritual do sacrifício humano que sempre atraiu Bataille. Trata-se de uma experiência que toca a imagem e o corpo de forma agônica, decompondo e desfigurando a forma humana ao máximo. O informe impõe um paradoxo de que a noção de figura pode permanecer dentro do espectro da humanidade mesmo que constantemente esmagada, esfolada, sacrificada, decomposta a seus caracteres mínimos (como o dedão do pé da figura 2). Bataille nomeia como "resíduo supremo" essa massa informe que define o destino de nossa semelhança (DIDI-HUBERMAN, 2015).

\section{O outro dessemelhante}

Diante do duplo estatuto do informe - operador conceitual e método de montagem dos objetos -, volto às imagens que são o ponto de partida desta discussão. Interessame levantar questionamentos sobre a outridade de figuras humanas que sofreram algum tipo de desfiguração, e em que medida essas figuras atestam um estatuto ontológico próprio que prescinda dos parâmetros miméticos ligados ao rosto, à doutrina das semelhanças e à demanda por identidade. Alteridade, aqui, não aparece mais como o reconhecimento da diferença, mas como um fenômeno em que a diferença é fabricada e acessada, tornando-se capaz de mover ou perturbar os estatutos de mesmo e de outro. Um pressuposto apressado pode nos levar a argumentar que é a forma monstruosa que é normal, uma vez que não existe um template humano que sirva de molde para todos os viventes, a não ser na dimensão mítica do homem feito de barro, ou nos levar à ideia de encarnação do espírito em um corpo mortal, imaginário que contribuiu para construir as noções de pessoa e de raça que se solidificaram no pensamento europeu após a Idade Média. O corpo, como o conhecemos atualmente, tem uma configuração mais heterogênea e diversa, seja por artifícios químicos ou maquínicos, seja por um alargamento das concepções humanistas sobre identidade e diversidade.

A diversidade e as transformações corpóreas, contudo, parecem caminhar junto à linguagem como um dispositivo de comunicação, de aperfeiçoamento ou de desconforto, 
mas vislumbrando a criação de um senso de comunidade, de formação de tribos baseadas em semelhanças, que, de algum modo, não abre mão de uma noção de template nem de mimese. O corpo sem rosto, por sua vez, surge nessa discussão como uma recusa ao senso de comunidade: mesmo encadeados lado a lado como uma galeria de retratos, os rostos que trazemos neste ensaio não contemplam uma comunidade, não olham uns para os outros como semelhantes, pois denotam justamente a impossibilidade de comunicação, de vínculo, de narrativização da experiência. Os corpos sem rosto olham, por outro lado, para o espectador. Essa devolução do olhar inquieta as possibilidades de reconhecimento na/da diferença. A forma deixa de ser, portanto, "critério absoluto de identidade, e mesmo de uma substancialidade" (DIDI-HUBERMAN, 2015, p. 149).

O informe convoca a possibilidade de uma "semelhança transgressiva". A noção de transgressão, no léxico batailleano, relaciona-se diretamente ao conceito de excesso e de dispêndio, de modo que o informe impõe o contato com o outro ao exceder as semelhanças. O informe propõe um vínculo entre imagem e ato de olhar, e entre imagem e outras imagens, a partir de uma semelhança forjada (como na figura 2, em que um dedão do pé convoca todo o corpo humano), um vínculo que não se baseia no reconhecimento, nem na informação estética, na qual forma e conteúdo se completariam em uma mensagem, tampouco na interpretação da forma. A semelhança é mantida pela negação, pelo dessemelhante, pelo que é excesso, dispêndio de energia sacrificial. Os rostos desfigurados ou decompostos vibram como um outro existente justamente nessa dimensão dispendiosa, que excede e que tem um fim em si, a dimensão do gesto.

Agamben (2008) inicia suas notas sobre o gesto com a assertiva de que, no século XIX, a burguesia ocidental já tinha perdido os seus gestos. A frase, ao utilizar o "já", soa como certa denúncia sobre a perda do gesto na cotidianidade urbana, indo encontrar lugar nos tratados de patologias psicossomáticas, como a Síndrome de Tourette, cujos sintomas resultam em uma "proliferação de tiques, tanto motores quanto verbais, que impedem o paciente de realizar mesmo os mais simples movimentos corpóreos" (AGAMBEN, 2018, $\mathrm{s} / \mathrm{p}$ ). A espontaneidade e autonomia dos gestos estudados por Gilles de la Tourette levam Agamben a pensar o gesto fora do domínio da patologia e trazê-lo para uma esfera ética do agir humano. O gesto pode ser pensado como um meio sem fim, ou ainda um "meio puro", ações sem intenção de comunicação, pura medialidade.

O conceito de gesto encontra eco na noção de dispêndio elaborada por Bataille, que discute atos que têm um fim em si mesmos, orientados pela noção contraprodutiva do gasto, do valor de uso, do escoamento dos excessos, do mesmo modo que o gesto tem a liberdade de não ter uma finalidade, sendo pura potência. "O que caracteriza o gesto é que, nele, não se produz, nem se age, mas se assume e suporta. Isto é, o gesto abre a esfera do ethos como esfera mais própria do homem" (AGAMBEN, 2018, p.12). O gesto, como o dispêndio, apresenta-se como posição epistemológica na compreensão das ações humanas, como um contraponto aos atos intencionais de comunicação, informação e de conservação da linguagem como distintivo de identificação. 
Nossa apresentação do gesto como meio puro, isto é, como exposição de uma medialidade sem fim e comunicação não de algo, mas de uma comunicabilidade, implica - ou, antes, exige - que tentemos definir de algum modo sua consistência ontológica. Se o gesto é caracterizado pela parada e pela suspensão, nas quais se dá a conhecer apenas uma cognoscibilidade, isso significa que ele tem apenas uma realidade negativa, da ordem não de um ser, mas de um não-ser? (AGAMBEN, 2008, s/p).

As imagens mostradas abrem para o espectador essa ambígua potência do gesto, como comunicação pura, como comunicação em si, mas que traz em seu cerne o espectro da incomunicabilidade provocada pelo rosto informe, um rosto que não completa o estádio do espelho lacaniano e que jamais se verá refletido na economia simbólica dos rostos contemporâneos (cinema, publicidade, redes sociais). A contextualização histórica ou semiótica desses rostos nos levaria a operações férteis no que concerne à crítica social, à denúncia de violência doméstica, aos dilemas da bioética etc. Entretanto, esses retratos, aqui recortados e montados em conjunto, impedem a fabulação simbólica tradicional, na qual um significante e um significado correspondem-se com um mínimo de interferências e operam um sentido comunicável.

O rosto como instituição cultural opera como um símbolo coeso, cuja identidade, mesmo sob disfarces, mantém-se como o ente que liga a alma ao corpo, que traz a substância à tona, revelando sua identidade e seu lugar individual no mundo. Além do senso de identidade, o rosto, como discute José Gil (1997), opera como o topos de recepção por natureza: inscrito em um circuito de fala entre um locutor e um interlocutor, o rosto seria essa superfície neutra a quem a mensagem se dirige, que revelaria o sujeito cognitivo apto a receber e decodificar aquele conjunto de signos. O rosto é, portanto, "uma superfície particular de entrada do exterior para o interior" (GIL, 1997, p. 167), que ao mesmo tempo opera como índice de uma interioridade inerente. Desse modo:

Dirigir-se a uma cabeça sem rosto equivale a dirigir-se a ninguém - porque não haveria já um 'lugar' a partir do qual situar o outro como receptor das mensagens verbais (a relação dialógica desapareceria). O rosto oferece esse lugar de que necessita todo o sentido; e, assim, ele centra o sentido. De tal modo que se pode dizer que não há sentido sem rosto porque há um rosto do sentido (GIL, 1997, p. 166).

Gil dá continuidade às discussões empreendidas por Deleuze e Guattari (1996) no platô Ano zero - rostidade, no qual os autores exploram uma semiótica mista (única semiótica possível, para eles) composta por um cruzamento de dois eixos, a saber, subjetivação e significância. O rosto, desse modo, opera nessa dupla semiótica como um sistema composto por muro branco, referente à significância, em que os signos se inscrevem, e buraco negro, em que a subjetivação aloja sua consciência, sua paixão 
e suas redundâncias (DELEUZE; GUATTARI, 1996). Os autores reiteram que a rostidade, como um processo de territorialização, define zonas que direcionam as expressões fluidas às significâncias estanques e conformes, além de formar um "lugar de ressonância" que ancora as consciências e as paixões, formas ativas da subjetividade. Sem um lugar onde as instâncias da significância e da subjetividade possam criar território, sua ação permaneceria vazia de sentido. Dessa forma, os autores reiteram a ideia de uma máquina abstrata que fabrica rostos como ambiências do social, que contempla o sistema muro branco-buraco negro.

Os rostos concretos nascem de uma máquina abstrata de rostidade, que irá produzi-los ao mesmo tempo que der ao significante seu muro branco, à subjetividade seu buraco negro. O sistema buraco negro-muro branco não seria então já um rosto, seria a máquina abstrata que o produz, segundo as combinações deformáveis de suas engrenagens (DELEUZE; GUATTARI, 1996, p. 30).

O gesto proposto pelos retratos sem rosto coloca a experiência da visualidade em uma encruzilhada, que traz o ruído para o centro da visualidade e que impede o processo de territorialização explicado por Deleuze e Guattari: há significância e há subjetivação, mas não como um operador conjunto, como sintagma e paradigma de uma única operação da linguagem. Como significantes puros, e ao mesmo tempo flutuantes, os rostos desfigurados que temos não completam a aventura semiológica. Antes, prescindem da significação em nome de uma significância que move de lugar certo status das teorias da comunicação. Refiro-me aqui, especificamente, à teoria matemática da comunicação e a saberes dela herdeiros, que postulam que uma boa comunicação é aquela que completa o percurso entre emissor e receptor de modo eficaz.

A ideia de significante flutuante decorre da discussão sobre o pensamento simbólico na obra de Lévi-Strauss (2008), mais especificamente a partir de dois ensaios sobre a cura xamanística. O significante flutuante coloca um problema semiótico para os processos de identificação, pois deriva de um excesso de significação que não encontrou aderência a um referente. Esse excesso tem valor semiológico nulo, mas valor material profícuo nos processos de formação de sentido, pois ocupa zonas de desordem semântica, geralmente fronteiriças, nas quais ocorrem uma intensa troca e tradução de signos, tornando os sistemas culturais mais complexos ${ }^{3}$. O contato com essa desordem da significação gera um hiato de compreensão dos signos, sendo necessário, portanto, um logos simbólico que possa acessar as particularidades da vida sensível e do pensamento mágico.

3 Uma construção semelhante pode ser encontrada no pensamento do semioticista luri Lotman, notadamente seu conceito de fronteira, espaço semiótico em que são encontrados filtros tradutores responsáveis por regular a entrada de signos novos em sistema de sentido. O conceito de fronteira de Lotman esquematiza um processo de comunicação no qual o ruído e os excessos de significância, bem como signos ambivalentes, são considerados como parte estrutural dos processos de comunicação, e não como empecilhos à semiose. Adequar o ruído por meio da tradução faz, no pensamento de Lotman, com que os sistemas simbólicos operem de modo mais complexo e dinâmico. Cf. Lotman, 2000. 
Pois apenas a história da função simbólica permitiria dar conta dessa condição espiritual do homem, na qual o universo nunca significa o bastante, e o pensamento sempre dispõe de um excedente de significações para a quantidade de objetos aos quais pode associá-las. Dilacerado entre esses dois sistemas de referência, o do significante e o do significado, o homem pede ao pensamento mágico para fornecer-lhe um novo sistema de referência, no qual os dados até então contraditórios possam ser integrados (LÉVI-STRAUSS, 2008, p. 262).

As experiências de des-rostificação sugerem para nosso conjunto de personagens a necessidade de um novo processo de subjetivação que independa do reconhecimento especular humanista e de uma proposta de compreensão que parta de um novo sistema de referências. Esses personagens apresentam-se como pura imagem sem significado, como seres que existem em si, como potências do gesto, ou como dispêndio. Caricaturas da forma que reafirmam que as coisas não demandam formas fixas. O rosto negativo vai na contramão, por exemplo, dos estudos criminalistas sobre a face, populares no século XIX, ou ainda das assertivas sobre mulheres histéricas estudadas por Charcot (figura 3): rostos que expressam a substância, como saída do interior para o exterior, como sintomas de algo mais elementar à condição humana, seja a mente, o espírito etc. O inconsciente fala por meio dos sintomas, dirá a psicanálise freudiana. Que inconsciente se expressa em um rosto decomposto por ácido? Esses rostos atualizam, como imagem pura, a própria invisibilidade do rosto na esfera do visível.

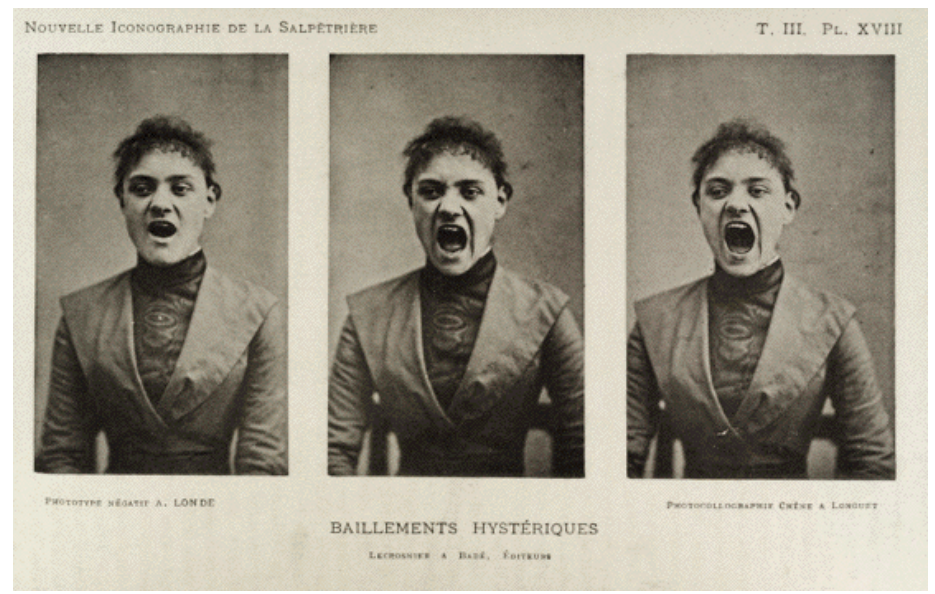

Fig. 3. Paciente histérica do hospital Salpêtrière de Paris, fotografada por Albert Londe, 1892

Situamo-nos, portanto, na ambiguidade desveladora do gesto e do informe, que pronuncia ao mesmo tempo que denuncia a ausência do rosto, que é iconoclasta e iconófilo simultaneamente. Trata-se de um domínio que excede a imagem como símbolo, como 
pátria da estética, relacionando o gesto do rosto sem feições a uma esfera da política e da ética (AGAMBEN, 2008). Estamos diante de uma política das imagens que clamam à existência um humanismo diverso, sem os vícios antropocêntricos ocidentais, sustentados por dicotomias metafísicas persistentes, como natureza e cultura, corpo e espírito, mesmo e outro. É possível dizer que a moça leprosa que passa maquiagem diante do espelho é o meu outro? No que toca à semelhança, qual medida possível de alteridade podemos percorrer até que esse outro se perca em uma diferença radical?

Nesse sentido, a economia das imagens propostas aqui, rostos com um mínimo de elementos distintivos, quase sem detalhes, satura a imagem em sua esfera de exibição, em um movimento de recusa à aura, como corpos sem espírito, como resíduos da destruição do corpo que não é nada além do que se vê, e ao mesmo tempo de convocação da existência justamente pela via da negação, como um gesto biopolítico do sensível. Esse movimento contraditório encontra pouso na própria ideia de presentidade ${ }^{4}$ dessas imagens: mesmo sem rosto, trata-se de retratos, inseridos em um regime representativo da imagem que repete uma mimese da organização do quadro, fotografado ou filmado, ao mesmo tempo que são rostos para os quais é impossível estabelecer qualquer relação mimética com o outro, com o espectador, apontando para um iconoclasmo e para uma iconofilia estruturantes, que negam a imagem ao reafirmá-la como elogio à superfície.

\section{Considerações finais}

Em um mundo em que a disposição de rostos tem uma rotatividade tão intensa selfies, redes sociais, documentos de identidade, aplicativos de reconhecimento facial etc. -, a atual noção de retrato de identificação faz reverberar uma economia simbólica outra. Na experiência das identidades pós-modernas, afirma Michel Maffesoli (2007), a subjetividade adquire um contínuo e dinâmico enraizamento em avatares distintos, e o compartilhamento de imagens de si focadas no rosto põe em movimento a circularidade dessas personas. Sob essa condição, o informe é capaz de figurar como nosso outro, uma vez que o reconhecimento especular não é viável. Sobre o humanismo da figura decomposta em Bataille, Eliane Robert de Moares (2002) afirma que a decomposição da fisionomia instaura uma resistência do antropos na imagem. Uma vez destruída, não há mais poder capaz de ameaçá-la. Diz a autora: "despossuído de tudo, o ser humano se torna enfim uma presença silenciosa que nenhum poder pode suprimir" (MORAES, 2002, p. 152).

Retorno à questão que abre este ensaio: que alteridade é possível aos corpos sem rosto? A natureza deste ensaio não permite, nem pretende, formular respostas definitivas a essa questão. $\mathrm{O}$ intuito da discussão partiu da necessidade de pensar outros critérios e outras epistemologias para a economia de alteridades na cultura visual contemporânea, de modo que o informe, categoria que põe em movimento conceitos e estatutos estanques,

4 Em um sentido de produção de presença discutido por Gumbrecht, 2010. 
sugere um caminho heterogêneo para pensar as tradicionais noções de mesmo e de outro, ou de identidade e diferença. Nesse sentido, o texto buscou pensar as possibilidades outras de acessar a diferença que não as tradicionais relações entre fisionomia, mimese e reconhecimento, reafirmando o pressuposto com que inicio este artigo, de que é na ambiência do sensível que os rostos desfigurados, rostos irreconhecíveis, encontram ontologia e pensatividade próprias, a despeito da noção humanista de pessoa como um sujeito da enunciação, como portador de um discurso socialmente reconhecível. O que torna evidente que os critérios de identificação historicamente relacionados à noção de pessoa, seja o rosto, os documentos de identidade ou impressões digitais, são culturalmente instituídos e insuficientes do ponto de vista da diversidade da figura humana.

João Victor de Sousa Cavalcante é doutorando no Programa de Pós-Graduação em Comunicação da Universidade Federal de Pernambuco (UFPE); é mestre em Comunicação pela Universidade Federal do Ceará (UFC). É pesquisador do grupo Narrativas Imaginárias (UFPE) e do Imago: laboratório de estudos de estética e imagem (UFC).

joaosc88@gmail.com

\section{Referências}

ABE, K. O rosto de um outro. São Paulo: Cosac Naify, 2015.

AGAMBEN, G. Para uma ontologia e uma política do gesto. Flanagens. Disponível em: http://flanagens. blogspot.com.br/2018/03/para-uma-ontologia-e-uma-politica-do.html?m=1 . Acesso em: jan. 2019. . Notas sobre o Gesto. Artefilosofia. Ouro Preto, n.4, p. 09-14. Jan. 2008.

BATAILLE, G. O Erotismo. São Paulo: Editora Autêntica, 2013a.

. A parte maldita (precedida da Noção de Dispêndio). São Paulo: Editora Autêntica, 2013b.

1986.

Visions of Excess: select writings, 1927 - 1939. Minneapolis: University of Minnesota Press,

Documents. Florianópolis: Editora Cultura e Barbárie, 2018.

BENJAMIM, W. Magia e Técnica, Arte e Política. São Paulo: Editora Brasiliense, 1985.

CRARY, J. Técnicas do observador. Rio de Janeiro: Editora Contraponto, 2012.

DELEUZE, G.; GUATTARI, F. Mil Platôs - capitalismo e esquizofrenia. Volume III. Rio de Janeiro: Editora 34, 1996.

DIDI-HUBERMAN, G. A semelhança informe: ou o gaio saber visual segundo Georges Bataille. Rio de Janeiro: Editora Contraponto, 2015.

GIL, J. As metamorfoses do corpo. Lisboa: Editora Relógio d'água, 1997. 
GUMBRECHT, H. U. Produção de Presença. Rio de Janeiro: Editora Contraponto, 2010.

LÉVI-STRAUSS, C. Antropologia Estrutural. São Paulo: Cosac Naify, 2008.

LOTMAN, I.; USPENSKI, B. Sobre el mecanismo semiótico de la cultura. La semiosfera III: semiótica de lãs artes y de la cultura. Madrid: Editora Cátedra, 2000.

MAFFESOLI, M. O ritmo da vida: variações sobre o imaginário pós-moderno. Rio de Janeiro: Record, 2007.

MORAES, E. R. O Corpo Impossível - a decomposição da figura humana: de Lautreamont a Bataille. São Paulo: Iluminuras, 2002.

Artigo recebido em 20/07/2019

e aprovado em 31/01/2020. 